ARTICLE

DOI: $10.1057 /$ s41599-017-0061-9

\title{
The Prevent strategy and the UK 'war on terror': embedding infrastructures of surveillance in Muslim communities
}

Fahid Qurashi ${ }^{1}$

\begin{abstract}
The Prevent policy was introduced in the UK in 2003 as part of an overall post 9/11 counter-terrorism approach (CONTEST), with the aim of preventing the radicalisation of individuals to terrorism. In 2015, the Prevent policy became a legal duty for public sector institutions, and as such, its reach has extended much deeper into society. This article, based on ongoing ethnographic fieldwork-including interviews, focus groups and participant observations-seeks to uncover and analyse the function of surveillance at the heart of the Prevent strategy. Contrary to official denials, surveillance forms an essential feature of the Prevent strategy. It regards radicalisation as part of an overall conveyor belt to terrorism, and thus attempts to control the future by acting in the present. The article shows how the framing of the terror threat in the 'war on terror', as an 'Islamic threat', has afforded a surveillance infrastructure, embedded into Muslim communities, which has securitised relations with local authorities. Its intelligence products, as well as the affective consequences of surveillance, have served to contain and direct Muslim political agency. Such an analysis uncovers the practice of Islamophobia at the heart of the Prevent strategy, which accounts for its surveillance tendencies.
\end{abstract}

\footnotetext{
${ }^{1}$ School of Law, Policing and Forensics, Staffordshire University, Stoke on Trent, Staffordshire ST4 2DE, UK. Correspondence and requests for materials should be addressed to F.Q. (email: fahid.qurashi@staffs.ac.uk)
} 


\section{Introduction}

he Prevent strategy is one strand of the UK counterterrorism strategy, CONTEST. It was introduced in 2003 by the New Labour government of Tony Blair. Initially, Prevent played a minor role in CONTEST relative to the other strands. But following the attacks in London on 7th July 2005, the importance of the Prevent strategy increased as the government sought to deal with a risk of 'home-grown' terrorism. At its core, the Prevent strategy was built to be the 'hearts and minds' dimension of the overall CONTEST strategy. It aims to prevent radicalisation to terrorism and has three strategic objectives to that end: (1) respond to the ideological challenge of terrorism; (2) prevent people from being drawn into terrorism and ensure that they are given appropriate advice and support; and (3) work with sectors and institutions where there are risks of radicalisation (HM Government, 2011a). In 2015, the Prevent strategy was placed on a legal footing in the Counter-Terrorism and Security Act, so that specified authorities such as Higher Education Institutions, need to have 'due regard to the need to prevent people from being drawn into terrorism' (HM Government, 2015, p 2). Since then, specified authorities have been creating and implementing policies and procedures that demonstrate compliance with this new Prevent Duty (see Qurashi, 2017). A partnership approach with Muslim communities has been at the heart of delivering these Prevent objectives.

Using data from ongoing ethnographic fieldwork - including interviews, focus groups, and participant observations - the article argues that this dynamic of the Prevent strategy has been used to develop infrastructures of embedded surveillance in Muslim communities. Using Sayyid's $(2010,1997)$ formulation of Islamophobia, as a racist practice that contains Muslim political agency, the article argues that the intelligence products of the embedded infrastructures of surveillance, as well as the affective consequences of Prevent surveillance, have served to contain and direct Muslim political agency and activism.

\section{Islamophobia and the 'war on terror'}

The 'war on terror' has come to define this era for Muslims in Britain. It touches every aspect of life, from birth to death, in every space that Muslims inhabit: the home; schools, colleges, and universities; mosques; community centres; and public spaces. Whether it be Schedule 7 stops at UK ports, ${ }^{1}$ stop and search by police officers, Prevent referrals to the Channel programme, ${ }^{2}$ experiences of institutionalised Islamophobia, or violent racist attacks, the overt focus on Muslims and Islam in the "war on terror' has energised Islamophobia and enhanced the precariousness of the Muslim experience in Britain. To uncover the political dimensions of Islamophobia in UK counter-terrorism (specifically the Prevent strategy), I move beyond simple characterisations of Islamophobia that focus on irrational bigoted individuals on the extremes of the political spectrum, by using Sayyid's (2010, 1997) formulation of Islamophobia: a racist practice that aims to stifle and contain Muslim political agency. This extends an analysis of Islamophobia from the fringes of society to the mainstream, from a practice that is the preserve of extremist individuals and groups, to one that is deeply embedded in society - legally, culturally, and psychologically. By using this approach, the aim is to analyse Islamophobia at an institutional level, as a conscious strategy and practice of power, as it is embedded into policies and practices that routinely privilege white interests and contain the interests of ethnic minority groups. This approach unpicks the Islamophobia which is endemic and ingrained and which appears as a normal, harmless, mundane feature of society, infused into a wide range of policies and practices, which, regardless of intent, reinforce and reproduce racism (Gillborn, 2008). In short, it seeks to disrupt the normalised forms of Islamophobia as well as the more exceptional forms. The end goal is to demonstrate how the racist outcomes of social policies, such as counter-terrorism policies, are far from accidental, but rather are a reflection of the racist politics and practices of power that underpin them (Gillborn, 2008). In the context of the Prevent strategy, this framework offers a way of making sense of its disproportionate impact on Muslim communities.

The universalising essence of Islamophobia, which casts all Muslims and Islam as uncivilised, barbaric and threatening, is culturally rooted in the west and operationalises Islamophobia through beliefs, ideas, tropes and analyses about Muslims and Islam on which the containment and disciplining of Muslims and Islam is situated and justified (Fawzi, 2015; Said, 2003). Muslim political agency refers to an engagement with politics that is based on an Islamic discourse, symbolism and practice (Birt, 2010). Islamophobia encapsulates a fear and disdain of this agency in the public space and aims to suppress Islamic politics, identities, and bodies through institutional structures, and contain Muslims within national borders (by articulating national Muslim identities) to stem a broader mobilisation of Muslims across the world. Contemporary manifestations of Islamophobia emerged during the latter part of the twentieth century, at which point Islamic revivalism was underpinning the political mobilisation of Muslims and an assertion of Muslim identity across Europe (equality and human rights), and the world (anti-colonial struggles). Islamophobia emerged at this point in history to discipline Muslims and reinforce a hierarchy between the west and Islam, and between Europeanness and non-Europeanness, which was being challenged by Muslims that were making politically significant claims, and presenting different political possibilities (Sayyid, 2010). In short, Islamophobia emerged at a time when traditional hierarchies were breaking down, and it served to remind Muslims of their inferior status and contain any political mobilisation and claims making (hence the prevalence of Islamophobia across all sectors of society, from housing to education, reminding and disciplining Muslims at every turn).

Framed in this way, an understanding of Islamophobia goes beyond simple negative characterisations of Muslims and Islam and taps into and reflects a historical management of Muslims (and broader black and ethnic minority groups) that accounts for historical inequities. Furthermore, as Sian (2015) argues, such a view of Islamophobia shifts the focus away from individual incidents towards the structural operations of power that govern Muslims and the conditions within which violent and non-violent incidents occur. In this paper, I argue that Islamophobia (enabled by practices of surveillance), rather than any counter-terror logic, operates as the central organising logic of the 'war on terror'.

\section{Islamophobia and the historical containment of 'Others'}

The strategies of containing and managing Muslim agency emerge from the European colonial era management of 'Others': from physical containment strategies such as the use of Passbooks, slave passes, and the use of disproportionate levels of violence to contain agitation by slaves (Parenti, 2003); to the more traditional use of informants, and police forces, to monitor groups and individuals with the aim of identifying those resisting colonialism as it sought to militarily invade, occupy, conquer, and socially engineer indigenous populations with reference to western capitalist ideals (Monaghan, 2013); to reinforcing colonial racial hierarchies by enforcing racial segregation to minimise mixing and marriage (Sa'di, 2012); to the more recent practice during the era of slavery and Jim Crow in America of (violently) 
suppressing the black gaze in the presence of whites to enforce an inferior status and contain claims and agitations for equality (hooks, 1992; Browne, 2012). Since then, as ethnic minorities have slowly entered institutional spaces Collins (1998) argues a new politics of containment has emerged, in which surveillance strategies are used to ensure ethnic minorities are unraced so as not to challenge the whiteness of institutional spaces (Mirza, 2006).

As surveillance has been embedded into the fabric of society, the management and containment of populations has reached new heights of sophistication. Surveillance practices and capabilities provide the state enhanced forms of visibility to effect containment strategies that ensure its dominance (Fiske, 1998). For instance, cities are more precisely zoned in ways that ensure ethnic and religious minorities are contained within particular geographic spaces, and marked as being out of place when they transgress the boundaries (Hesse, 1997). Futhermore, with the intensification of globalisation, European states have moved towards the direct management of religious minorities by adopting repressive strategies of containment. Some of these strategies include the creation of enclaves to quarantine religious minorities away from mainstream society, which results in the deprivation of mobility and universal rights afforded to citizens (Turner, 2007). Surveillance technologies are increasingly implicated in these strategies as they are used to create technological rings of steel. Project Champion in Birmingham, in which covert and overt Automatic Number Plate Recognition (ANPR) cameras were placed in predominantly Muslim parts of the city, was an instance of this trend. (Lewis, 2010).

In an era of globalisation characterised by mobility, these strategies of containment operating at a national level, have been extended to operate across the world to manage and contain global mobilities. Shamir (2005) identifies the emergence of a global mobility regime underpinned by a paradigm of suspicion that operates to treat people differently: to enable the movement of those considered 'safe' while containing and blocking the movement of those constructed as 'dangerous'. Surveillance practices play a key role in the global management and containment of populations and have led to the emergence of a global Banopticon (Bigo, 2008), which is in part aimed at containing foreigners on the margins. It is made up of a heterogeneous set of discourses, institutions, architectural structures, laws and administrative measures. As it is concerned with the management of unease, the Banopticon unearths a different set of motives, to countering terrorism, that sit behind surveillance practices: 'keeping the poorest foreigners at a distance, through controlling the flux of mobile populations' (Bigo, 2008: p. 18). This logic means that the surveillance of those characterised as 'suspect' and 'dangerous', as opposed to the universal surveillance of wider society, sits at the heart of policing.

\section{Containment, surveillance and soul training}

The attempts to contain a particular population and its political agency using surveillance technologies, is a prelude to a broader strategy of social engineering and discipline aimed at inclusion into a western capitalist order. Using surveillance to manage and contain a population provides the necessary detailed knowledge to 'see' it and break it down into governable units (Haggerty, 2006). The surveillance gaze allows for a population to be known which is a prerequisite for it to become a site of action: identifying the 'risks' that need to be neutralised; the unacceptable, abnormal behaviours and ideas that need to be disciplined by way of extending social norms to mould ideas and behaviours (Fiske, 1998). In the panopticon model, Foucault identified this as a process of 'soul training' that was aimed at the automatic functioning of power: to transform individuals so that they monitored their own behaviour in line with prescribed social norms, to the extent that there was a realignment of the boundaries between the 'acceptable' and 'unacceptable', and the 'normal' and 'abnormal' (Lyon, 1994; Foucault, 1991).

The power of surveillance to demonise people, conduct, and ideas is not always informed by the criminal justice imperative of the rule of law, where only those engaged in obviously criminal conduct are targeted by surveillance practices for 'soul training' and inclusion. Historically, surveillance was at the heart of colonial projects, monitoring the adoption and resistance to imposed European ideals and practices, and monitoring traces of indigeneity that threatened colonial projects. Those that adopted European ideals and conduct were labelled 'good' and marked for inclusion, while those that opposed them were considered 'bad', excluded, and marked for intervention. Therefore, surveillance has been at the heart of the demonisation of expressions of indigeneity, and the promotion of 'Europeanness' as 'good' and aspirational, as it enabled the capitalist colonial project of expansionism (Monaghan, 2013).

To be included is to be integrated into the norms, behaviours, values, ideas, consciousness, emotions and cognitions of society (in place of one's own outlook) that can reproduce western modes of life (Sa'di, 2012). In the 'war on terror', a key component of deradicalisation programmes hinges on a cultural transformation of Muslim identity to view the west and all it stands for (its ways of life, values, and politics) with a more positive attitude. Prowestern or 'moderate' Muslims are rewarded by being valued as 'true' Muslims, their interpretations and religious traditions are elevated as true reflections of Islam, and they are often referred to as representatives of the Muslim community. If strategies of inclusion fail, then the individual is purposefully excluded from mainstream society and marked as a threat, for intervention, as the final option. Exclusion is aimed at protecting mainstream society by preventing the excluded subjects from reaching, communicating, and working with mainstream society. It enables and legitimises the use of violence, coercion, and intense surveillance, all of which can violate basic human rights (Kundnani, 2014).

\section{The Prevent strategy and the containment of Muslims and Islam}

In the UK dimension of the global 'war on terror', the Prevent strategy (HM Government, 2011a) occupies a central role, and is a continuation of historical strategies of containment aimed at 'Others'. Although it was introduced with the seemingly positive goal of preventing radicalisation to terrorism in the UK, and political leaders claim (out of necessity) that it targets all threats of terrorism and extremism, what is clear, is that counterterrorism practice (particularly in the Prevent strategy) targets Muslims in general, and in many cases where there is no suspicion or evidence of criminal activity (Cohen and Tufail, 2017; Versi, 2017). It is therefore difficult to sustain an argument about the operation of (Prevent) counter-terrorism as a response to a terror threat.

Instead, the Prevent strategy has been at the forefront of disseminating and normalising Islamophobia across society, by inscribing its assumptions and prejudices into the structural operation of numerous institutions, and shaping the practices of public sector employees. In the strategy, the problem of extremism and terrorism is closely tied to Muslims and Islam, so that the terror threat is regarded as an Islamic threat. Others, such as Davies (2016), have argued that although the policy document does refer to other groups and forms of terrorism (such as right 
wing terrorism), the thrust of the policy is about Islamic terrorism. Furthermore, its emphasis on teaching 'British values' suggests its focus is on those who do not authentically (know how to) practice Britishness. Framing the threat in this way not only 'others' Muslims, but the 'otherness' narrows the public perception of Muslims down to terrorist violence and inscribes the characteristics onto the public consciousness, further normalising Islamophobia. The normalisation augments the state's ability to use enhanced forms of social control, exclusion, and violence against Muslim communities.

The overarching framework that associates Muslims and Islam with terrorism is mirrored in policy discourse in which there are regular associations between Muslims and Islam and extremist and terrorist activity. For instance, a 2007 document produced by the Department for Communities and Local Government (DCLG, 2007: p. 7) offered guidance to evaluate the effective use of Prevent counter-terrorism funding in the following way: 'The key measure of success will be demonstrable changes in attitudes among Muslims, and wider communities they are part of, locally and nationally'. The guidance refers to Muslims in general and 'wider communities' as opposed to individuals and groups suspected of criminal activity. This kind of policy discourse often works its way into political and media rhetoric as its normalising power imbues politicians and media outlets with a 'retaliatory confidence' (Gillborn, 2008), in the name of security, to enhance social control and state power. Blanket approaches to counterterrorism such as this play on orientalist cultural narratives of an ever present Islamic threat to the west. Indeed, the cultural 'threat' of Islam, characterised as 'non-violent extremism' in the Prevent strategy, has come to dominate the construction of Islam in the public imagination such that it has become common place to view Muslims and Islam through this lens (exemplified in the Trojan Horse affair, see Miah, 2017). The underlying notion here of a threat emerging from Islam to the west has long existed and over the past few decades has primarily been articulated through Samuel Huntington's 'clash of civilisations' thesis (Huntington, 1996), which suggests a threat from a clashing of civilizational values: the threat to enlightened western ideals and values from a fundamentalist and illiberal Islamic world. In recent times a liberal variation of this narrative has emerged that points not to Islam itself, but to 'warped interpretations' of Islam by extremists as the source of threat to the west (Kundnani, 2014). Orientalist narratives of this kind function to reinforce the perception that 'Islamic terrorism' somehow emerges from, or is indeed rooted in, Islamic doctrine and practice, rather than the social and political realities of the world, and in turn, situates Islam itself as the source of the threat.

Framing the terror threat in this way (as an Islamic threat) means that the infrastructure and focus of counter-terrorism practices, such as surveillance, are overwhelmingly directed at Muslims. For instance, when Prevent counter-terrorism funding was distributed by central government to local authorities, it was done so in direct proportion to the number of Muslims in a local authority area (Kundnani, 2009; DCLG, 2007). More recently, Cobain et al., (2016) and Hayes and Qureshi (2016) have shown how the counter-terror work of the Research and Information Communications Unit (RICU) at the Home Office focuses on Muslims as its target audience, and its counter-terrorism research focuses on Muslims and Islam. For example, between 2007-2010, RICU research projects investigated the following issues: 'How young British Muslims felt about their identity and sense of belonging'; 'How young British Muslims use the internet'; 'How government messages are perceived by Muslim communities'; 'Islamic blogs'; 'The language of terrorism'; and 'Why some voices are more credible than others to Muslim communities'. It is, therefore, not surprising that given the discursive characterisation of the terror threat as an Islamic threat, and the Muslim-centric nature of counter-terror practice, that Muslims make up an overwhelming proportion of referrals to the Channel programme. For instance, data published following two freedom of information requests shows that: between April 2007 and December 2010, $67 \%$ of Prevent referrals involved Muslims, between April 2012 and January 2014 that figure was 57.4\% (Traquair, 2014); and between April 2012 and April 2015 at least 69\% of the referrals involved Muslims, and between April 2015 and April 2016 at least $68 \%$ of the referrals involved Muslims (Traquair, 2016). This is despite the fact that, according to the last census in 2011, Muslims make up $4.8 \%$ of the population of England and Wales (Ali, 2015).

\section{Surveillance and the Prevent strategy in the 'war on terror'}

Surveillance is at the heart of containment mechanisms in the Prevent strategy and it has fundamentally reshaped relations between Muslims, the state, and wider society. The strategy's focus on prevention leads it to conceive of radicalisation as a process driven by an ideology. Prevent awareness training (such as the Home Office Workshop to Raise Awareness about Prevent) theorises that a terrorist attack is the end point of a process, or the tip of an iceberg. In order to monitor the process, and identify individuals on the path to radicalisation, the job of Prevent work is to encourage vigilance and to look for signs, ${ }^{3}$ such as behavioural changes, that would indicate a person is on a conveyor belt of radicalisation to terrorism. Since the vast majority of the iceberg is not easily visible it has to be made visible by strategies of surveillance and monitoring, to allow interventions in the process (HM Government, 2011a). This view of radicalisation and terrorism moves Prevent counter-terrorism into the precrime domain of pre-emption, which is built upon strategies of surveillance (Qurashi, 2017). In order to predict and pre-empt an action, there needs to be some level of intelligence to inform decision making. As such, surveillance in the Prevent strategy is not an aberration, or the product of poor practice, but an inbuilt feature of a strategy that is oriented to acting on the future. As part of similar counter-terrorism strategies in the United States of America, investigative journalism has uncovered widespread organised surveillance of specifically Muslim communities, businesses and organisations under the guise of community engagement (Aaronson, 2013; CBS/AP, 2012).

There are some indications that intelligence gathering has been at the heart of Prevent practice. For example, in 2009 Ed Hussain of the Quilliam Foundation (which received $£ 700,000$ for Prevent related work in that year) said of Prevent, 'It is gathering intelligence on people not committing terrorist offences' (Dodd, 2009). More recently, following the terrorist attack on Manchester in 2017, Home Secretary Amber Rudd countered claims on an episode of Question Time, that cuts to police funding may have impeded the prevention of the terror attack. Instead she said, 'We get the intelligence much more from the Prevent strategy, which engages with local community groups, not through the police' (The Guardian, 2017).

Despite this, there have been longstanding denials from the Home Office about allegations of spying as part of the Prevent strategy. For example, the 2011 Prevent Review stated 'Prevent project funding was not conditional on the disclosure of sensitive personal information...there was no evidence that data was being collected as a matter of course on a wide range of personal issues...the report accepted that the allegations about data sharing were based on a misunderstanding about the process for supporting vulnerable people' (HM Government, 2011a: p. 31). Rather, the review claimed that information was only collected for community mapping and project monitoring. 


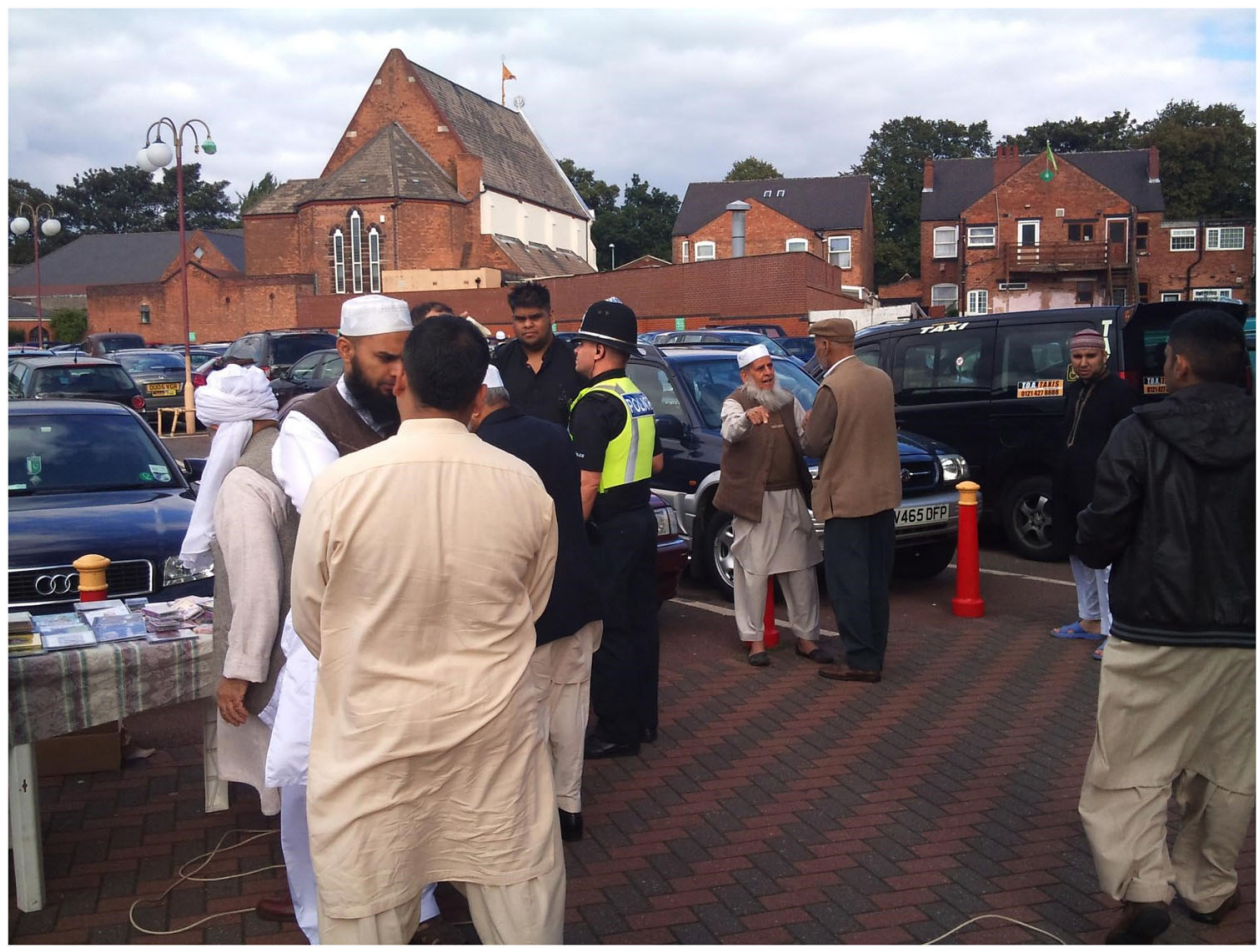

Fig. 1 Police officer outside a mosque after Juma (Friday prayer). This figure is covered by the Creative Commons Attribution 4.0 International License

\section{Democratising counter-terrorism: inviting Muslims into institutional spaces and laying the foundations for Prevent surveillance}

However, several Muslim organisations across the country funded by the Prevent strategy, claimed that police and Prevent officers regularly requested, by pestering and pressuring, for specific detailed information about the young Muslims using their services. Using ethnographic data, the next part of the article demonstrates how infrastructures of surveillance have been created in Muslim communities using the Prevent strategy.

The policing and surveillance of Muslim communities in the 'war on terror' occurs on multiple levels. The more overt and apparent strategies involve CCTV surveillance (at times in a targeted fashion, such as Project Champion in Birmingham), and higher levels of policing. Across all of the research sites, the high level of policing of Muslim communities was a constant theme of daily field notes. The noise of police sirens, overhead helicopters, the flashing of police lights, police and police community support officers patrolling the streets in large numbers, police in cars, CCTV vans, riot vans, police on bikes, on horseback, and in unmarked cars made it clear during fieldwork that these communities were being heavily policed. At peak times outside mosques (Friday prayers and during Ramadan) there was always a police presence (police officers either standing outside or driving by in CCTV vans); Fig. 1).

But since the introduction of the Prevent strategy a new layer of surveillance in Muslim communities has been built, enabled by a policy agenda of direct community engagement operationalised by the institutionalisation of relations between local authorities and local communities. Direct community engagement, in the form of building networks, fortifying relations and inviting local voluntary organisations into institutionalised spaces, was a policy agenda most strongly adopted and championed by the New Labour government in 1997. New Labour wanted to move beyond the confines of the market and the state and adopt a 'third way' approach, characterised by partnerships and community engagement via funded forums, councils and panels, to issues such as welfare, social exclusion and the modernisation of local government, which would provide a space and voice for local voluntary organisations in the policy making process (Farrelly and Sullivan, 2010; Taylor, 2007; Taylor et al., 2004). The rationale for this direct form of community engagement was to address a democratic deficit by encouraging politicians and policy makers to listen and respond to the needs of the people, particularly those excluded from decision making such as ethnic minorities, and by doing so, improve public service delivery (Cornwall, 2004). Moving away from the Conservative Party's individualised concept of the citizen, in these developments New Labour aimed to responsibilise citizens to create their own welfare (Barnes et al., 2004). These new spaces are characterised as 'invited spaces' to symbolise the power relations in the spaces, which can be opened and closed by the local authority (Cornwall, 2004).

Rather than heralding neighbourhood renewal, these new governance spaces mask new forms of state control given the power imbalances, ongoing attempts of re-centralisation, and practices of co-option. As 'invited spaces', they are inscribed with the rationalities of the state and the economy, which exercise significant influence in directing the rules and agendas to the detriment of local communal priorities and goals, so that community participants feel they have a small voice, little power and limited impact. In this context, in an attempt to acquire greater power, voice and impact, some community actors internalise the rationalities and objectives of the state and economy to demonstrate their capabilities for governing in ways that suit the dominant powerful state actors (Farrelly and Sullivan, 2010; Taylor, 2007).

Direct community engagement with Muslim communities to deliver the objectives of the Prevent strategy was built upon an institutionalisation of relations between local authority 
organisations (such as the police, Prevent officers and local authority officers) and Muslim civil society organisations (such as mosques, community centres and youth clubs that received Prevent funding). A pretext of project management and support allowed local authority figures to meet regularly (at least once per week, often more regularly depending on the number of sessions per week) with the Prevent funded organisations and build informal and formal (institutionalised) relations. However, local authorities have used these opportunities and pretexts to saturate large parts of Muslim communities and build infrastructures of surveillance.

The institutionalisation of relations with Muslim communities to deliver the Prevent strategy needs to be situated in this context, in which local authorities attempted to gain a level of buy-in from Muslim communities and responsibilise them to take a role in counter-terrorism in their own communities. Muslim actors internalising the objectives of the Prevent strategy and implementing them in their own communities, was a more effective method of achieving the counter-terrorism objectives, than using a more hierarchical approach involving external actors from police forces and local authorities. This approach was particularly important for the Prevent strategy given that, I would argue, a rationale of surveillance underpinned Muslim community engagement. This form of engagement lends itself to mapping and documenting Muslim communities, because as research on covert policing shows (O'Neill and Loftus, 2013), partnerships are conducive to the development of trust because they place various actors in close proximity for prolonged periods of time, and to the routine unquestioned nature of collection and sharing of increasingly sensitive intelligence.

Institutionalised relations between Muslim civil society organisations and various local authority organisations (whether it is the local police, counter-terrorism unit (CTU) or Prevent officers) have been cultivated in various ways. For Muslim organisations, access to new sources of funding was a major factor that informed their decision to engage with local authorities on the Prevent agenda. The funding from the Prevent stream provided a much needed income, and engaging with the Prevent agenda also raised the profile of an organisation. For local authorities, however, engagement with particular Muslim organisations was in part determined by the size and reach of their network into the local Muslim community.

As local authorities received Prevent funding from central government, local Prevent officers consulted with Muslim civil society organisations to raise awareness about the availability of new Prevent funding, about the kinds of projects that they should create (such as youth leadership programmes), and encouraged them to submit applications. Those organisations that were interested in applying for the Prevent funds were supported by Prevent officers through the application process, and applications were assessed at commissioning panels.

The process of institutionalisation. One Muslim youth organisation in Birmingham, formed and led by Aleesha and some core members, to provide educational support for local young people, decided to apply for Prevent funding:

\section{'So how did the idea of this organisation start?'}

'Me and another girl, we used to just meet and talk about issues in our community and how there are a lot of issues in our community that need addressing, and how no one is doing anything about them. So we said, "let's do something about this instead of complaining". So, we set up this organisation which Alhamdulillah is doing really well. So, for the first year, we just did workshops and circles with the girls, you know, and we invited speakers to give talks.'

\section{'How long have you been going?'}

'We've been going three years. The first year was just informal when we met for halaqah's [circles] and did workshops occasionally. We want to be able to offer our youth role models so they don't feel lost and they can take some inspiration to do well.'

\section{'How did you decide that you needed Prevent funding for this project?'}

'There's only so much you can do on a voluntary basis. For example, we have our workshops. But we need a venue for that. Initially we relied on donations from parents but there's only so much parents can donate. The other thing was, we needed more dedicated staff, because we were all volunteers, and someone who could work dedicated constantly. We needed more dedicated staff because the numbers grew and so we needed more staff. The current situation wasn't sustainable because we got married, had kids, and had more responsibilities as well.'

\section{'So basically you grew to a point where you could no} longer remain as a voluntary organisation?'

'Yeah that's right. We have too many kids on our list; even at the halaqah's we have lots of people. We didn't know where to do go for funding so we asked around a few people in key places, how they applied, and got advice on applying for funding. We spoke to people in the council who worked on PREVENT and in our area and on the same issues. We tried to apply for funding but we needed better advice. So then the head of PREVENT in Birmingham approached us and he's a policeman. A year before he approached us, he did get in touch and asked if he could work with us.'

\section{'Why did he get in touch with you?'}

We needed money and he knew one of the council workers we approached and he found out that we were applying for funding. And he thought it would be good to have a link with the police. So I wrote this funding application and it was crap. If that was me giving the funding I wouldn't have funded that application. But the PREVENT people said "yeah yeah have the money". We were like "Alhamdulillah, thank you."

\section{'How much did they give you if you don't mind me asking?'}

'It was just about $£ 50,000$ staggered quarterly for 1 year. We never asked for that much initially. Originally we applied for $£ 30,000$ but then we had to up it because we couldn't stretch that to what we needed it for. So we had to go back and ask them for more and they OK-ed it.'

\section{'So it seems like it was pretty easy to get that money.'}

'Uh-huh yeah it was. It was easy because they knew us and they knew we had contacts in the community and we were working with young Muslims. We have a good network in the community and we link with the parents, especially the mothers, and that's important because they run the family.' 
Another Muslim youth organisation in Leeds began with similarly humble roots. They began as a small group of friends working with young Muslims in the local community on volunteering initiatives as a way of dealing with issues such as gang crime. One of the founders explains:

'Once we got a lot of numbers [of young Muslims] on our books the council took an interest.'

At this point they were encouraged by the local council to apply for Prevent funding, with the support of local Prevent officers:

'They wanted us to have Prevent funding because we did a lot of the ground work, we've got the access and the networks. And as part of that money they attached that former police officer to us, to babysit us, under the remit of professionalising our service, because they didn't think we had the infrastructure set up.'

One of the issues this illustrates is that the size and reach of an organisation's network into a Muslim community made it attractive for Prevent funding. In these cases, the organisations were known to Prevent officers in the local council, and had good networks with the local Muslim community. Even though the organisation in Birmingham felt their application was poor, they still received the initial $£ 30,000$, and they then successfully requested an additional $£ 20,000$. One way to read it would be to suggest that for the local Prevent board, transparency and access into an organisation with deep and broad roots into the Muslim community, was of more importance than the amount of money being spent or the kinds of projects that were created. What was striking about many of the organisations, such as the two above, that received Prevent funding, was that they did not always seem to be obvious choices to be working on preventing extremism related projects as their expertise lay elsewhere. However, a common feature of many Prevent funded organisations was their deep reach and network into their local Muslim community. While seemingly benign, this afforded local authorities a pathway of access into Muslim communities.

Not all Muslim organisations were comfortable working on the Prevent agenda, and in those cases, Prevent officers would attempt to exploit the financial insecurity of an organisation to exert some pressure on it to adopt the Prevent strategy. Two Muslim youth clubs, one in Leeds and another in Birmingham, both reported being pressured in this way. In Birmingham, Mahmoud had been looking for a new source of income (including from the local council) to fund his organisation. Prevent officers learned of his financial difficulties and would regularly contact him and encourage him to apply for Prevent funding:

'They were constantly pressuring me and telling me that if I took the Prevent money I could improve the services and prospects for the young people.'

Prevent funded Muslim organisations were targeted by a range of state actors, such as Prevent, police, and counter-terrorism officers, to establish close working relations and embed officers with the organisation. For instance, a Prevent funded organisation in Leeds, which held regular sports events for young people, would often see local police and Prevent officers attend its events. In fact, police, Prevent, and counter-terrorism officers were often present at a wide range of local community events, regardless of whether they were organised with Prevent funding or related to counter-terrorism matters. For instance, a public meeting about some green space that had been cleaned with community volunteers was attended by the local police, Prevent officers, counter-terrorism unit, probation service, and youth service.

\section{Embedding surveillance infrastructures into Muslim communities}

The institutionalisation of relations with Muslim civil society organisations, to deliver the Prevent agenda, served two functions. On the one hand, it operationalised New Labour policy mantras of 'community engagement' and 'double devolution' by responsibilising Muslim communities (Taylor, 2007). On the other hand, it served the surveillance imperative at the heart of the Prevent strategy.

At one level, embedded surveillance is an increasingly mundane feature of late modern life as it is embedded into the routines of everyday life, across private and public spaces (O'Neill and Loftus, 2013). A key function of embedded surveillance is the policing, control, and modification of criminal and non-criminal 'problematic' behaviours and ideas. In commercial environments surveillance is being embedded into urban regeneration projects to police the boundaries between those that belong and those that do not (Fussey and Coaffee, 2012). But within the context of a 'war on terror', embedded surveillance is tied to coercive practices of the military, counter-terrorism units and police officers. For instance, Graham (2006) argues that in the military, saturating and embedding surveillance into cities in the Global South, to achieve constant coverage and the ability to target anyone at any time, is at the heart of US military domination strategies. Embedded in this way, surveillance becomes persistent, provides a detailed map of the ground and allows surveillance infrastructures to constantly monitor for any changes that take place in an area, against a background of normality (Ackerman, 2002). In a military context this kind of persistent surveillance, which is enabled by embedded infrastructures of surveillance, is used to provide constant support for operations. Notions of 'Total Information Awareness', which emerged after 9/11, sit at the heart of embedded surveillance practices as they attempt to build three dimensional pictures of communities from a range of sources that supplement each other.

Prevent officers 'lifestyling' in Muslim communities. In the arena of domestic policing, covert officers embedding into communities fine tune their ability to operate in an environment and identify changes to their normal expectations, whether that be with people or events. Covert officers acquire detailed knowledge of their environments and their subjects over a prolonged period of time, learned by processes of 'lifestyling', so that they are effectively embedded and can reflect their environment and be able to identify changes that are out of the ordinary (Loftus and Goold, 2012).

In the UK's 'war on terror', the Prevent strategy has been used to create infrastructures of surveillance that connect Muslim communities to numerous local authority organisations. Meetings (both formal and informal) between Prevent funded Muslim civil society organisations and local authorities served two functions: firstly, to share new intelligence by sharing updates on local Prevent projects and on local developments; secondly, to allow Prevent and police officers to familiarise themselves, and become familiar, to the local Muslim community (in other words, a form of 'lifestyling'). In covert policing 'lifestyling' is essential in order to fit into an environment and to be able to collect a good amount of quality intelligence. This means that officers try and craft their appearance and behaviour in ways that correspond to the environment so as not to stand out (Loftus and Goold, 2012).

Credibility has been a key theme of several research projects carried out by RICU at the Home Office. For instance, RICU (2010) carried out research to identify the individuals and organisations that Muslims would find to be credible, and one 
of its findings related to the appearance and manner of people engaging with Muslim communities. It found that to be credible, a person should be, among other things, interested in the Muslim community, knowledgeable, be Islamic and strong in conviction (Sabir, 2017). In applying these findings, Prevent officers would often attempt to enhance their credibility by looking (for example, by wearing a prayer hat, traditional clothes, grow a beard, wear a hijab) and acting Islamic (for example, symbolising their Islamic authenticity by regularly making use of Islamic language, such as 'Alhamdulillah', 'Inshallah', and other phrases such as 'only Allah knows'). For instance, at a Prevent funded youth project in Leeds, I asked the supervising Prevent officer whether they would continue working in Prevent counter-terrorism for the foreseeable future, to which they replied: 'Who knows, only Allah knows'. At another Prevent funded project in London, a non-Muslim English Prevent officer would greet the Pakistani Muslims in the youth club with the Islamic greeting of peace, As-salamu-Aleikum (peace be upon you), and use the Urdu parting phrase, Khuda Hafiz (May God be your Guardian). One Friday, I came to the youth club later in the afternoon than I had for the previous four days and the Prevent officer asked me: 'You're in later than usual. Have you been to pray Juma (weekly Friday prayer)?'

As a source of intelligence, this infrastructure can continuously provide thick, detailed, textured, intimate information to Prevent and police officers on the activities, associations, behaviours, thoughts and ideas of (mostly young) Muslims in the vicinity of a Prevent funded project. Over the course of several years the individuals at the heart of the Prevent surveillance infrastructure have developed a strong familiarity with their particular local Muslim community (its politics, key individuals, organisations etc.) so that they can develop detailed localised analyses. A permanent base in the heart of local Muslim communities means surveillance and intelligence gathering is routine, unquestioned and mundane. One of the main functions of the surveillance infrastructure is to provide intelligence that would allow local authorities to contain and/or steer local Muslim politics, for example, by feeding the intelligence into related counterterrorism systems (such as 'Pursue,4), where it can be used for a range of policing activities (on the relationship between Prevent and Pursue, see Sabir, 2017).

In the first instance, Prevent officers regularly attended sessions organised by Prevent funded organisations (which started at various times, from morning sessions at 10.00 am to evening sessions at $8.00 \mathrm{pm}$ ) to establish a strong rapport and familiarity with the management and the service users. One evening session at a mosque in Leeds a Prevent officer, Michael, came and joined us in the office (myself and three other people that ran the youth session) as some young boys were kicking a football around outside. He came in to collect receipts so that some expenses could be reimbursed. After having collected the receipts however, Michael stayed with us in the office for the rest of the session (over an hour) and joined in our conversations about the mosque. That evening, a nearby (Prevent funded) youth club was not open for the evening session and Michael wanted to know the reason. Junaid explained that because of the cold weather and poor heating the youth workers decided it was better to cancel the session until the heating could be fixed. How did Michael know the other youth club was closed?

At another (Prevent funded) youth club in Leeds on another cold, wet evening, I was sat in the office with two of the senior youth workers talking about football when a Prevent officer, Syeeda, came in and joined us. There was no apparent reason for Syeeda's visit, and a few minutes later she said, 'I was just in the area so I thought I'd drop in'. She asked Bally and Danish how the session had been going, and if they had any trouble, specifically referring to two young Muslims. She made them aware of a Prevent funded residential trip she was organising for several youth clubs and asked them to identify a few of the young people for the trip. In particular, she asked Danish and Bally to pick people who needed some mentoring and support. The trip would focus on developing the kinds of skills that many Prevent projects focused on, such as leadership skills, so that young people were able to challenge different 'extremist' views. The trip would also be attended by an Imam, who had delivered Prevent projects in the region, and who was going to deliver talks on jihad and on the importance Islam places on respecting elders, community leaders, and parents. Within the context of the Prevent strategy, such talks delivered by imams, take on a political significance as they aim to deliver tailored messages to young Muslims. Syeeda asked Danish to approach the parents to get consent for the trip, despite the fact that she was organising the trip. For the parents, a known local Muslim face, as opposed to that of a Prevent officer, would make them more comfortable in agreeing to allow their children to attend the trip.

When she left an hour later, Bally and Danish turned to me and said,

'She does that all the time. She wasn't here to make small talk, on one of the coldest nights of the year. She came in to check whether we were open. It's her way of keeping an ear to the ground'.

As well as informal meetings such as this, Prevent funded organisations also held regular formal weekly and monthly meetings with a range of local authorities such as police, Prevent, and counter-terrorism officers. In Birmingham, Aleesha said these meetings were an obligation and they were arranged to feedback any new developments since the previous meeting. Many of the meetings were attended by individuals from several Prevent funded organisations in the local area and were useful for the officers to network with and develop a stronger familiarity. The aim of that was, according to Aleesha, to become comfortable with the officers so that they would feel comfortable sharing information.

For the young people in the youth clubs, the constant presence of local authorities was uncomfortable. At a Prevent funded youth club in Leeds, one of the boys complains to me: 'Why is he [Danish] always letting the 'maaveh' (police) in here?' Danish was very clear about the reasons behind their presence:

'I told them that's the price of opening a youth club. We wouldn't have been allowed to open otherwise. When they see that we engage with the police they say to us, 'are you off your rocker?!' Obviously they don't like that and don't want to be near the police because they're paranoid based on past experiences.'

Embedding into local Muslim organisations in this way is aimed at fostering a culture of surveillance. At a local council Prevent workshop in London, organised by Prevent officer John, and attended by Prevent officers, police officers, counterterrorism officers and youth workers, an outside 'terrorism expert' was invited to deliver a talk on radicalisation. He advised the group that they had an important role to play in preventing radicalisation, and that they could identify radicalisation, by looking for changes in young people in the following four areas: language, behaviour, peers and needs. If anyone noticed any changes in these areas, then they needed to raise the issue. This kind of mentoring is a necessary precursor, to mould people working in voluntary and statutory organisations, into vigilant actors capable of collecting and feeding intelligence into Prevent channels of communication. 
Intelligence gathering in Muslim communities. Primarily, surveillance of Muslim communities in the Prevent strategy is facilitated by Prevent officers that manage several Prevent funded projects in a local area. However, this is supplemented by local police officers and counter-terrorism officers. Several examples illustrate this.

Firstly, at the Prevent funded mosque in Leeds, I attended the youth sessions with Junaid, who was one of the committee members that ran the sessions. Some of the young people were playing football, others were playing together on an Xbox, and others were playing table tennis. I asked Junaid what had changed in the services they offered young people since they began receiving Prevent funding:

'Not much has changed for us. But obviously they [Prevent officers] want get in to the mosques and see who's using the services and if there's any dodgy characters that we need to pass onto them'.

At another Prevent funded youth club in Leeds, manager Haroon told me at one of the sessions that he had a meeting with local Prevent and police officers earlier in that week. When I asked him what they discussed, he told me:

'They're always pushing to do more partnership work because they get more access to us that way. They're always asking about the youngsters, what they're doing, what their views are, who they hang out with, and where they hang out'.

\section{'Do they ask you about the youngsters in their meetings with you?'}

'Yes of course, they ask us all the time. They want to know how many youths we have, how old they are, where they go after madrassa [evening class], how much time do they spend at these places, what do we teach them at madrassa. How can they expect us to know all this information? They still pester us about it all the time. They still ask us to keep an eye on the people that use the mosque for them'.

In line with other instances of direct community engagement in a range of social policy areas (Taylor, 2007), community participation in Prevent counter-terrorism is at times characterised by an internalisation of the rationale of Prevent (to protect funding), and at other times marked by tensions over competing agendas. Counter-terrorism governance spaces are inscribed with the rationale of surveillance, which sits at the heart of the Prevent strategy, and it meant that some organisations did not achieve their aims and goals. The constant demands for information from community organisations and the overt surveillance character to engagements with Prevent officers meant that, in some cases, relations broke down. For example, a youth club in London managed by Shaf, submitted an application for Prevent funding and used the money to create a leadership project to enhance leadership skills in the young Muslims that used the youth club. The project was a collaborative effort between the youth club, the local Prevent officers, the Metropolitan Police Service, and the local council. Shaf felt that the young Muslims needed role models and confidence in their ability to do what they wanted, go out in the world and be able to compete for the leading jobs across all sectors, and he felt leadership skills were a key component in building confidence. Now that the project had ended Shaf was very critical of the Prevent strategy. For him, Prevent was very much like a surveillance operation, in that, in some cases it was run by Prevent officers who were former police officers with an intelligence background or in close collaboration with them:
'This made it difficult to work together on the project because they all wanted to run the project more like a surveillance operation'.

Shaf had some very frank discussions with the Prevent and police officers after several requests to share information about the local Muslims: who used the youth club and the mosque, who distributed leaflets outside the mosque, what kinds of discussions did the youngsters have at the youth club, who did they associate within the community and so on. Shaf was clear he was not prepared to collect and share any intelligence. Despite protests from police and Prevent officers, he was adamant that the project would not be used as an intelligence gathering operation in the local Muslim community. This was the major stumbling block between them which strained the relationship.

Secondly, there were instances in which local counter-terrorism officers worked with Prevent officers. In Birmingham, youth club manager Musa was trying to identify new sources of income and was approached by a local Prevent officer with a view to applying for Prevent funding. The Prevent officer also involved local police and counter-terrorism officers with the youth club. One officer in particular, from the local counter-terrorism unit, was keen to recruit Musa as a 'trusted contact' so that they could work together for the benefit of the local Muslim community.

At the start of one of the youth sessions as everyone ran to start playing games, Musa came over to me and told me wanted to speak with me. He asked 'Can we go into the office because it's quite sensitive and I don't want to talk in front of all these people'. We went into the office and Musa took out a business card and handed it to me and said that this CTU officer had attended on several occasions to talk with him. The officer was keen to engage with Musa, and through him, with the wider Somali Muslim community. Musa complained that the officer always wanted to arrange another meeting and to speak with the young people that attended the sessions. He showed me some of the emails that he received, each beginning with 'As-salamu-Aleikum!' He was keen to learn about the Somali community and Somali culture and hoped Musa would give him some key insights. In another email, he asked Musa about some rumours he had heard about Somali parents confiscating their children's passports to prevent them from travelling to Somalia and joining Al-Shabaab. Was there any truth to these rumours? Are Somalis from Birmingham going to Somalia to fight? Musa felt that the officer wanted to know which parents had confiscated passports so that their children could be targeted by counter-terrorism officers. At one of the meetings Musa asked the CTU officer why he was keen to engage with him: was there evidence of terrorist activity in the community? The officer explained his model of radicalisation, which was steeped in Islamophobia, and clearly regurgitated from the Prevent policy document: this community has a high Muslim presence with a lot of young Muslims hanging out on street corners, which made them vulnerable to radicalisation by expert recruiters.

Musa felt that he was being groomed as a spy or contact in the Somali community for the officer, because he will have learned from the Prevent officer and through his own attendance at the youth sessions, that Musa's organisation had a good network in the Somali Muslim community. However, Musa did not want to engage with him and decided to ignore him:

'The pressure is immense. They want to be my friend so they can get access, they want me to collect personal information by spying for them. What can I do? I want to tell him to fuck off and leave me alone. But they can arrest me very easily'.

Given that Musa had arrived in the country from Somalia and was being targeted for information by a counter-terrorism officer 


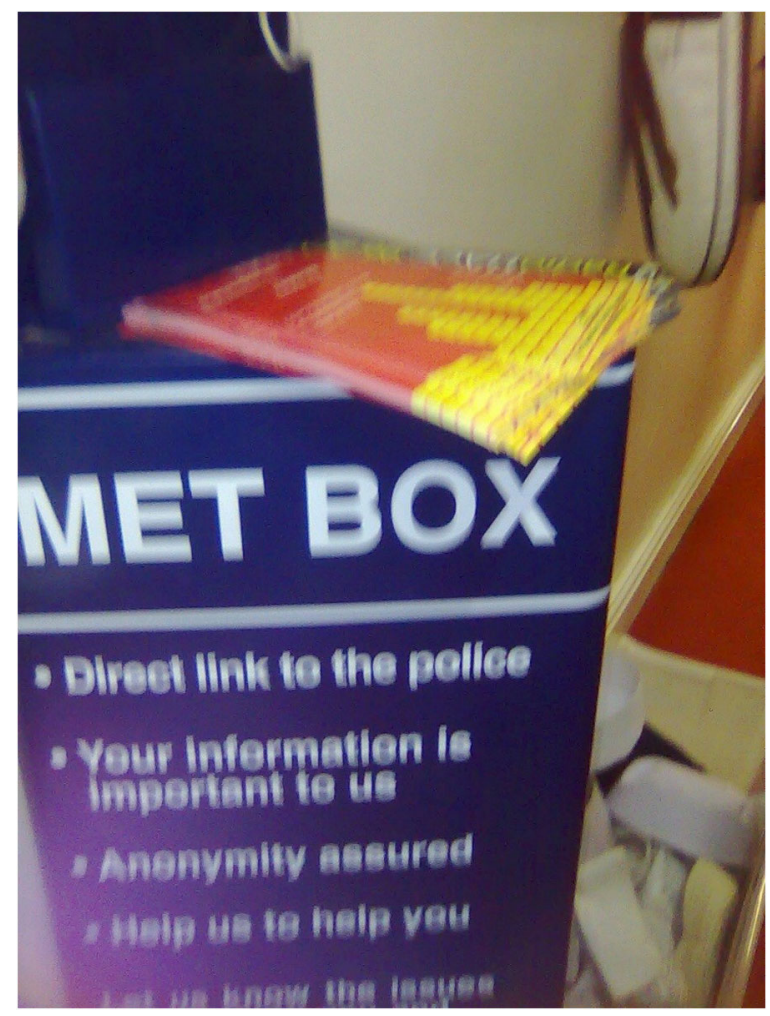

Fig. 2 'Met Box' at a mosque in London. This figure is covered by the Creative Commons Attribution 4.0 International License

who had powers of arrest, the emails were read as demands. The wider context of the 'war on terror' which produced regular news stories of high-profile arrests by counter-terrorism officers fuelled Musa's fears of being arrested. Despite this, Musa's relationship with the local Prevent officer fell apart because of these demands because he was not prepared to act as a spy. As a result, he did not apply for any Prevent funds.

These fears of surveillance permeated right across Muslim communities. In Birmingham, at the completion of a Prevent funded project at Aleesha's youth organisation, a presentation ceremony was arranged at which the young people received certificates. Among other people, the ceremony was attended by the local Prevent, police and counter-terrorism officers, which made Aleesha uncomfortable:

'But at that graduation I didn't want them anywhere near my kids to be frankly honest'.

\section{'Who didn't you want near your kids?'}

'Any of the Prevent people'.

\section{'Why?}

'Because they're all counter terrorism hawks and it's not good for my kids to be near them. I didn't want them speaking to my kids either. The information they enquired about, we gave them, but I didn't want them speaking to my kids'.

Thirdly, there were also some indications that local police officers had adopted the Prevent strategy in their engagement with Muslim communities. At a youth club in Birmingham I asked one of the youth workers about their engagement with the local police:
'The police come every two days, if not everyday, to check up on the people in the centre, which feels like they're spying. The police look at who is entering and using the youth centre. Some of us wear traditional clothes and they probably think we're radicalising the younger lads. When a regular face isn't present they ask us where he is'.

\section{The affects of Prevent surveillance}

The embedded surveillance of the Prevent strategy has produced strong cultures of suspicion and fear in Muslim communities. The presence and awareness of surveillance almost automatically produces a range of feelings and unconscious wordless states which induce particular emotional responses in certain spaces (Ellis et al., 2013). Surveillance therefore has significant affective consequences. For Muslims, in many cases surveillance is an everyday experience and is almost always experienced as oppressive and produces fear and apprehension as it monitors and records their performance of 'Britishness'. Given the allencompassing nature of the 'war on terror', these emotional reactions have become an ordinary part of everyday life for Muslims: at school; whilst socialising and shopping; on public transport; at work; at mosques and so on. As such, surveillance impacts the way in which power and social relations are experienced and understood (Koskela, 2000).

These implications of surveillance were manifest during all stages of fieldwork. Whether it was parents changing the youth club their child attended after learning it received Prevent funding, or young Muslims feeling unable to openly and freely discuss the politics of the 'war on terror', or express their religiosity and culture (by, for example, growing a beard, wearing a hijab, or wearing traditional clothes), there were underlying tensions. At a focus group in Leeds, a young Muslim articulates his apprehensions:

'I'll tell you how I see it. I see Muslims... as tongue tied. They have to be careful what they say so as to not say something out of line because anything you say today can be classed as "extremism". Because of that I think Muslims are restricted. We're under extreme stress, restricted. Our identity is being challenged; we're under the microscope a lot more. And the way we're defined keeps us under the microscope. We haven't got freedom of speech'.

Surveillance as part of the Prevent strategy plays a significant role in this apprehension because it is the most regular contact point between Muslims and the state on security matters. As a researcher working in this environment, the research process was constantly touched by it. There were two initial concerns that people had with my presence. First, was I a spy? The sheer number of Muslims interrogated at ports, in custody, and at home (HM Government, 2017) and encouraged to work, either for the police or a spy agency, as well as high-profile cases of spies posing as 'researchers' (Bano, 2011), meant that people were generally apprehensive about my presence. One person in London would cross the road every time he saw me walking in his direction. Second, once I had convinced a person I was not working as a spy, I was asked about the source of my research funding. At a youth club in London I initially introduced myself to a youth worker and talked about my research. The following day at the youth club, his brother was also present. Qasim was in the middle of a $\mathrm{PhD}$, and so, was familiar enough with research funding processes and research proposals at university to interrogate me. Who was funding the research? Was it a research council or a university scholarship? What were my research questions? What methodology was I using? What was my hypothesis? Had I reached any conclusions? I came to expect 
these kinds of questions as a natural consequence of the fears of surveillance in Muslim communities. 'You understand why we ask you, right?' was how Qasim put it.

\section{Directing and containing Islamic politics}

In this article I have demonstrated that from the Prevent strategy an infrastructure of surveillance has been created and embedded into Muslim communities. Prevent, police, and counter-terrorism officers are the key protagonists in the infrastructure as they seek out individuals and organisations to work with in Muslim communities and gain access to their networks. Although some of their conduct may seem innocent, the surveillance imperative at the heart of the Prevent strategy undermines assertions of innocence.

The intelligence gathered from this embedded infrastructure of surveillance, and its affective consequences, are at the heart of attempts to direct and contain Muslim politics and Islamic identities. Junaid gave me two examples of Prevent officers influencing the mosque. First, Hizb-ut-Tahrir (an Islamic political party) used to leaflet outside the mosque after Juma prayers but the committee banned them from leafletting. The local Prevent and police officers had raised the issue with the mosque committee, and because the committee did not want to jeopardise any funding, they agreed to ban the organisation from leafletting. Secondly, I asked Junaid how the Prevent funding had changed the service they offered the young people, and he informed me that for the most part, it remained the same. What had changed was that:

'We give them some more Islamic education and leadership skills so that if they come across a "radical" then they can identify them and challenge them, or let someone else know about it who can go in and deal with that person. We also use this programme to dialogue with teachers, parents and the authorities to work for the kids'.

In short, what had changed was that the Islamic identity of young Muslims at the mosque was being moulded, with tailored Islamic education classes and leadership workshops, in the interests of the state. The young Muslims were being equipped with a particular version of Islam and the leadership skills to promote it.

At other mosques in London, the Metropolitan Police Service installed a 'Met Box' with a pen attached, to allow mosque goers the opportunity to communicate with the police anonymously (Fig. 2).

Some of the Prevent funded organisations extended their reach beyond their immediate environment and their usual audience. In Leeds, Junaid and the mosque committee, used some of the Prevent funds to create mentoring projects in two local Leeds schools. They worked with the school to identify Muslim 'kids that are trouble causers and badly behaved' for individual mentoring. In London, Aleem's 15-year-old son was targeted for this kind of intervention by a Prevent funded organisation. Aleem said:

'They [school] picked kids who they thought were badly behaved. Apparently that made them vulnerable to extremism. They did some mentoring sessions and told the kids not to get involved in extremism'.

These examples illustrate some of the ways in which the Prevent surveillance infrastructure is used to contain and direct Muslim politics. It simultaneously operates on a general and particular level: it targets whole Muslim communities to identify potential 'extremists' and potentially risky individuals to be moulded into appropriate British citizens, whilst also seeking to identify those that that need to be marked for exclusion and passed onto the Pursue strategy. Channelling individuals marked as '(potential) extremists' into deradicalisation projects is an attempt to neutralise risks to the political status quo by remoulding identities and politics with reference to "British values'. In doing this, the state is engaged in attempts to socially engineer Muslim politics and political agency vis-à-vis its own politics by drawing boundaries around and defining 'good/bad' Muslim/Islam. In the first of Junaid's examples above, Hizb-utTahrir was banned from leafletting at the mosque because it falls outside the confines of acceptable Muslim Islamic politics. Banning the organisation sends a coercive signal to 'extremists' (about the unacceptable nature of their Islamic identity and politics) and 'moderates' (about the importance of staying within the confines of acceptability and keeping away from political positions from beyond the border lest they are subject to the same exclusionary practices). The cultures of suspicion and fear produced by this practice of surveillance in Muslim communities exercises significant influence on political agency. Intelligence gathering from surveillance practices is often the basis for high profile counter-terror raids and arrests which exerts further coercive pressures on Muslims as they are all potential targets.

As with the Home Office denials about allegations of spying in the Prevent agenda, Prevent officers that I interviewed rejected claims about Prevent surveillance in Muslim communities. These denials ranged from being outright ('that's bollocks'), to some acknowledgement of sinister behaviour by Prevent and police officers. Asked about the increasingly close ties between Prevent and police officers and Muslim civil society organisations, one Prevent officer responds:

'[Long silence, looking at the floor]. Hmm, good question. [Long silence]. There's no doubt that that started off as part of the government agenda around making links with Muslims, and they were I think, an easy place to come across the Muslim community, particularly the mosque. So we do have these meetings, but we see the mosques as the gateway into the community, rather than it being anything sinister. I think there is an element that does behave like this based on stereotypes, but the majority do it because they genuinely want to get to know the community. So if we say $70 \%$ is genuine because it's about community engagement, and about $30 \%$ is about wanting to see what's going on and is a bit more sinister'.

\section{Conclusion: Prevent and the normalisation of Islamophobia}

This article has sought to uncover and analyse the function of surveillance at the heart of the Prevent strategy. The article shows how the framing of the terror threat in the 'war on terror' has afforded a surveillance infrastructure, embedded into Muslim communities, which has securitised relations with local authorities. Its intelligence products, as well as the affective consequences of surveillance, have served to contain and direct Muslim political agency. Using empirical data, the article uncovers the Islamophobic function of counter-terrorism surveillance in the Prevent strategy.

The surveillance of the Prevent strategy is Islamophobic surveillance because it is informed by the framing of the terror threat as an Islamic threat, which casts all Muslims as potential terrorists that need to be monitored and categorised. The location, language, values, and image of terrorists, and the terror threat, are thus predominantly gauged against a standard notion of normality, the vantage point from which surveillance and counterterrorism is directed, which is racialized and which results in an uneven surveillance gaze (Fiske, 1998). Focussing on Muslims, 
Prevent surveillance operates to identify and categorise Muslims on the basis of a dichotomy that is infused with Islamophobic tropes, into 'good' safe 'moderate' Muslims and 'bad' dangerous 'extremist' Muslims, and is used to police and reinforce this boundary (Mamdani, 2005). These decisions are made on the basis of political positions vis-à-vis the state, the 'war on terror', the language and framework that Muslims chose to use to articulate their political activism and ideas, and how they look and dress. In other words, the Islamophobic surveillance of the Prevent strategy aims to regulate the conduct of Muslims as British citizens with 'British values' by demonising everything else (Fiske, 1998). Those that are deemed to be 'bad' Muslims and are not authentically performing Britishness, in the first instance, need to be moulded into good British Muslim citizens (using 'deradicalisation' programmes, for instance), and their inclusion needs to be monitored. If this fails, and the Prevent strategy is unable to effect containment, then they are passed from Prevent to other parts of the counter-terrorism structure (such as Pursue) for the purposes of exclusion and neutralisation. As such, the Prevent strategy is an instance and a continuation of the historical strategies of containment targeting 'Others'. The Prevent infrastructure of surveillance is built using local community actors and organisations, and it is used to monitor the politics of Muslims and socially engineer those with risky unacceptable politics. Consider, for example, Prevent interventions in the public sector, buttressed by demonising and fear inducing discourses of 'entryism', for making claims for equality in the provision of prayer space, dress code and taking pro-Palestinian political positions (Rights Watch, 2016; Prevent Watch, 2016; Bouattia, 2015). The embedded nature of Prevent surveillance in Muslim communities, which provides a constant, textured, intimate image, allows for a more efficient monitoring of change against a background of normality learned over a prolonged period of time, and thus a more efficient containment of undesirable politics.

The operation of the Prevent strategy illustrates the way in which a logic of Islamophobia sits at the heart of the "war on terror', characterises its main tendencies, and is normalised by an ever growing 'war on terror'. In particular, Islamophobia is normalised in the 'war on terror' as it is transposed into the more acceptable language of security. Beratan (2008, p 337) uses the concept of transposition to explain 'a history in which all victories or progress have been almost immediately undermined through systemic mechanisms that serve to maintain existing discrimination'. The threat of terrorism allows the state to contain Muslim political agency, by characterising that which is undesirable as a threat, to be dealt with by the apparatus of social control. Hall and Scraton (1981, p 408) argue, "[the criminal label] can sometimes be applied to activities which the authorities oppose, not because they are "criminal" but because they are politically threatening. In such circumstances, "criminalisation" can provide the justification for political containment. "Criminalisation" is a particularly powerful weapon, when used in this way, because it mobilizes considerable popular approval and legitimacy behind the state. People are more likely to support state action against a "criminal" act than they would the use of the law to repress a "political" cause.' Techniques of transposition hide and mask the Islamophobic character of surveillance in the Prevent strategy, and in doing so, normalise and mainstream notions of Islamic threat and Muslim barbarity. By transposing the goal of 'containing Muslim political agency' into the key of 'security against terrorism', the Prevent strategy is able to practice Islamophobia, because the acceptability of trading liberties for security allows claims against the Prevent strategy to be dismissed as necessary in the fight against terrorism.
Received: 27 August 2017 Accepted: 14 December 2017

Published online: 13 February 2018

\section{Notes}

1 Schedule 7 of the Terrorism Act 2000 allows the police to stop and search people at UK ports without any 'reasonable suspicion' of involvement in terrorism. The police can search and seize any items, download and store data from electronic devices, take fingerprints and a DNA sample, and compel a person to answer questions without access to a lawyer (failure to do so is a criminal offence).

2 The Channel programme is connected to the Prevent strategy and provides a mechanism for referring 'radicalised' individuals or those considered vulnerable to 'radicalisation' (HM Government, 2010).

3 The Channel Vulnerability Assessment Framework identifies 22 factors of radicalisation (HM Government, 2012).

4 'Pursue' is one part of the CONTEST strategy and aims to prevent terrorist attacks by using detection, prosecution, and disruption tactics (HM Government, 2011b).

\section{References}

Aaronson T (2013) The terror factory: Inside the FBI's manufactured war on terrorism. Ig Publishing, New York

Ackerman RK (2002) 'Persistent surveillance comes into view', in Signal Magazine, May. Available at: http://www.afcea.org/signal/articles/anmviewer.asp?a=97. Accessed 24 Jan 2017

Ali S (2015) British Muslims in numbers: A demographic, socioeconomic, health profile of Muslims in Britain drawing on the 2011 Census. Muslim Council of Britain, London

Bano R (2011) 'Community rift over undercover police in mosques', BBC Asian Network. 24 Nov

Barnes M, Sullivan H, Knops A, Newman J (2004) Power, participation \& political renewal-issues from a study of public participation in two English cities. Inst Dev Stud Bull 35(2):58-66

BBC (2011) 'Birmingham Project Champion 'spy' cameras being removed'. 9 May Beratan GD (2008) The song remains the same: transposition and the disproportionate representation of minority students in special education. Race Ethn Educ 11(4):337-354

Bigo D (2008) Globalized (in)security: the field and the ban-opticon. In: Bigo D, Tsoukala A (eds) Terror, insecurity and liberty: Illiberal practices of liberal regimes after 9/11. Routledge, London and New York, p 10-48

Birt Y (2010) Governing Muslims after 9/11. In: Sayyid S, Vakil A (eds) Thinking through islamophobia-global perspectives. Hurst, London, p 117-128

Bouattia M (2015) Preventing PREVENT. National Union of Studens, London

Browne S (2012) Race and surveillance. In: Ball K, Haggerty K, Lyon D (eds) Routledge handbook of surveillance studies. Routledge, London and New York, p 72-79

CBS/AP (2012) NYPD built secret files on Newark mosques. 22 Feb

Cobain I, Ross A, Evans R, Mahmood M (2016) Inside Ricu, the shadowy propaganda unit inspired by the Cold War, in The Guardian. 3rd May

Cohen B, Tufail W (2017) Prevent and the normalization of Islamophobia. In: Elahi F, Khan O (eds) Islamophobia: still a challenge for us all. Runnymede, London, p 41-45

Collins PH (1998) Fighting Words: black women and the search for justice. University of Minnesota Press, Minnesota

Cornwall A (2004) New democratic spaces? The politics and dynamics of institutionalised participation. Inst Dev Stud Bull 35(2):1-10

Davies L (2016) Security, extremism and education: Safeguarding or surveillance? Br J Educ Stud 64(1):1-19

Department for Communities and Local Government (DCLG) (2007) Preventing violent extremism pathfinder fund: guidance note for government offices and local authorities in England. Department of Communities and Local Government, London

Dodd V (2009) Spying morally right, says thinktank, in The Guardian. 16th Oct

Ellis D, Tucker I, Harper D (2013) The affective atmospheres of surveillance. Theory Psychol 23(6):716-731

Farrelly M, Sullivan H (2010) Discourses of democracy in neighborhood governance. Critical Policy Studies 4(3):234-249

Fawzi S (2015) Social and political Islamophobia: Stereotyping, surveillance and silencing. In:Tottoli R (ed) Routledge Handbook of Islam in the West. Routledge, London and New York, p 229-243

Fiske J (1998) Surveilling the city: whiteness, the black man and democratic totalitarianism. Theory, Cult Soc 15(2):67-88

Foucault M (1991) Discipline and Punish: the birth of the prison. Penguin Books, Trans. Alan Sheridan. London 
Fussey P, Coaffee J (2012) Urban spaces of surveillance. In: Ball K, Haggerty K, Lyon DRoutledge handbook of surveillance studies. Routledge, London and New York, p 201-208

Gillborn D (2008) Racism and education: coincidence or conspiracy. Routledge, London and New York

Graham S (2006) Surveillance, urbanisation, and the US 'revolution in military affairs'. In: Lyon D (ed) Theorizing surveillance-the panopticon and beyond. Willan Publishing, Devon and Portland, p 247-269

Haggerty K (2006) Tear down the walls: on demolishing the panopticon. In: Lyon D (ed) Theorizing surveillance-the panopticon and beyond. Willan Publishing, Devon and Portland, $\mathrm{p}$ 23-45

Hall S, Scraton P (1981) Law, class and control. In: Fitzgerald M, McLennan G, Pawson J (eds) Crime and society: Readings in history and theory. Routledge and The Open University Press, London

Hayes B, Qureshi A (2016) We are completely independent: the Home Office, Breakthrough Media and the PREVENT counter narrative industry. CAGE, London

Hesse B (1997) White governmentality: Urbanism, Nationalism, Racism. In: Westwood S, Williams Jimagining cities. Routledge, London, $\mathrm{p}$ 85-103

HM Government (2010) Channel: Supporting individuals vulnerable to recruitment by violent extremists. The Stationary Office, UK

HM Government (2011a) Prevent strategy. The Stationary Office, UK

HM Government (2011b) CONTEST: The United Kingdom's strategy for countering terrorism. The Stationary Office, UK

HM Government (2012) Channel: Vulnerability assessment framework. Stationary Office, London

HM Government (2015) Prevent Duty Guidance: For England and Wales. The Stationery Office, London

HM Government (2017) Operation of police powers under the Terrorism Act 2000 and subsequent legislation: Arrests, outcomes, and stop and search, Great Britain, financial year ending 31 March 2017. The Stationary Office, London

hooks B (1992) Black Looks: race and representation. South End Press, Boston, MA

Huntington S (1996) The clash of civilisations and the remaking of world order. Simon and Schuster, New York

Koskela H (2000) 'The gaze without eyes': video-surveillance and the changing nature of urban space'. Prog Hum Geogr 24(2):243-265

Kundnani A (2014) The Muslims are coming: Islamophobia, extremism, and the domestic war on terror. Verso Books, London and New York

Kundnani A (2009) Spooked!: How not to prevent violent extremism.Institute of Race Relations, London

Lewis, P (2010) 'Surveillance cameras in Birmingham track Muslims' every move', in The Guardian. 4 Jun

Loftus B, Goold B (2012) Covert surveillance and the invisibilities of policing. Criminol Crim Justice 12(3):275-288

Lyon D (1994) The electronic eye: the rise of surveillance society. University of Minnesota Press, Minneapolis

Mamdani M (2005) Good Muslim, Bad Muslim: America, the cold war, and the roots of terror. Three Leaves Publishing, New York

Miah S (2017) Muslims, schooling and security:Trojan horse, prevent and racial politics. Palgrave Macmillan, Switzerland

Mirza HS (2006) Transcendence over diversity: black women in the academy. Policy Futures Educ 4(2):101-113

Monaghan J (2013) Settler governmentality and racializing surveillance in Canada's North-West. Can J Sociol 38(4):487-508

O'Neill M, Loftus B (2013) Policing \& the surveillance of the Marginal-Everyday contexts of social control. Theor Criminol 17(4):437-454

Parenti C (2003) The Soft Cage: Surveillance in America from slave passes to the war on terror. Basic Books, New York

Prevent Watch (2016) 'The Hijab Case'. Available at: http://www.preventwatch. org/the-hijab-case/. Accessed: 20 Dec 2017

Qurashi F (2017) Just get on with it: Implementing the Prevent duty in higher education and the role of academic expertise. Educ, Citizsh, Social Justice 12 (3):197-212

Research, Information and Communicati ons Unit (RICU) (2010) Credible voices: Exploring perceptions of trust and credibility in Muslim communities.Stationary Office, London
Rights Watch (2016) Preventing Education? Human rights and the counterterrorism policy in schools. Rights Watch, London

Sa'di A (2012) Colonialism and surveillance. In: Ball K, Haggerty K, Lyon D (eds) Routledge handbook of surveillance studies. Routledge, London and New York, p 151-158

Sabir R (2017) Blurred lines and false Dichotomies-Integrating counterinsurgency into the UK's domestic 'war on terror'. Crit Social Policy 37(2):1-23

Said E (2003) Orientalism. Penguin Books, London

Sayyid S (1997) A Fundamental fear-eurocentrism \& the emergence of islamism. Zed Books, London and New York

Sayyid S (2010) Out of the devil's dictionary. In: Sayyid S, Vakil A (eds) Thinking through Islamophobia-global perspectives. Hurst, London, p 5-18

Shamir R (2005) Without borders-notes on globalization as a mobility regime Sociol Theory 23(2):197-217

Sian KP (2015) Spies, surveillance and stakeouts: monitoring Muslim moves in British state schools. Race Ethn Educ 18(2):183-201

Taylor M (2007) Community participation in the real world: opportunities and pitfalls in new governance spaces. Urban Stud 44(2):297-317

Taylor M, Craig G, Monro S, Parkes T, Warburton D, Wilkinson M (2004) A Seachange or a swamp-new spaces for voluntary sector engagement in governance in the UK. Inst Dev Stud Bull 35(2):67-75

The Guardian (2017) Amber Rudd denies cuts to police were factor in Manchester atrocity. 25 May

Traquair S (2014) Freedom of information request reference number: 000117/13, Information released to MrWhitehead. Association of Chief Police Officers (ACPO). 24 Jan 2014

Traquair S (2016) Freedom of information request reference number: 000117/13 Association of Chief Police Officers (ACPO)

Turner B (2007) Managing religions: state responses to religious diversity. Contemp Islam 1(2):123-137

Versi M (2017) The latest Prevent figures show why the strategy needs an independent review, in The Guardian. 10th November

\section{Data availability}

Data sharing not applicable to this article as no data sets were generated or analysed during the current study.

\section{Additional information}

Competing interests: The author declares no competing financial interests.

Reprints and permission information is available online at http://www.nature.com/ reprints

Publisher's note: Springer Nature remains neutral with regard to jurisdictional claims in published maps and institutional affiliations.

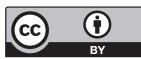

Open Access This article is licensed under a Creative Commons Attribution 4.0 International License, which permits use, sharing, adaptation, distribution and reproduction in any medium or format, as long as you give appropriate credit to the original author(s) and the source, provide a link to the Creative Commons license, and indicate if changes were made. The images or other third party material in this article are included in the article's Creative Commons license, unless indicated otherwise in a credit line to the material. If material is not included in the article's Creative Commons license and your intended use is not permitted by statutory regulation or exceeds the permitted use, you will need to obtain permission directly from the copyright holder. To view a copy of this license, visit http://creativecommons.org/ licenses/by/4.0/

(c) The Author(s) 2018 